American Journal of Applied Sciences 7 (6): 815-822, 2010

ISSN 1546-9239

(C) 2010Science Publications

\title{
Surface Modification of Mild Steel Using Tungsten Inert Gas Torch Surface Cladding
}

\author{
S. Dyuti, S. Mridha and S.K. Shaha \\ Department of Manufacturing and Materials Engineering, \\ International Islamic University Malaysia, P.O. Box 10, 50728 Kuala Lumpur, Malaysia
}

\begin{abstract}
Problem statement: There is an increasing demand for claddings which possess an optimized combination of different functional properties such as high hardness, high resistance to wear and oxidation. In this respect, hard TiAlN cladding has gained much attention. These claddings can be suitable replacements for the conventional ceramic coatings applied in many components of chemical plants and automotive industries to protect against high temperature oxidation and wear. Approach: In this study the possibility of the formation of intermetallic and nitride claddings on plain carbon steel surfaces by in situ melting of preplaced titanium and aluminum powder mixture under Tungsten Inert Gas (TIG) torch had been investigated. Results: Addition of 1.3 and $1.8 \mathrm{mg} \mathrm{mm}^{-2} \mathrm{Ti}$ and $\mathrm{Al}$ powder and melting at energy inputs between $540-675 \mathrm{~J} \mathrm{~mm}^{-1}$ in nitrogen environment successfully created more than $1 \mathrm{~mm}$ thick clad layer consisting of a mixture of titanium-aluminum nitrides and aluminides. All resolidified melt layers produced dendrite microstructures; the dendrite concentration is more near the surface area compared to the deeper melt depth. A maximum surface hardness of around $900 \mathrm{Hv}$ was developed in most of the tracks and this hardness corresponds to high concentration of dendrites within the modified layer. Oxidation at $600^{\circ} \mathrm{C}$ for $72 \mathrm{~h}$, of the clad steel gave weight gains of $0.13 \mathrm{mg} \mathrm{mm}^{-2}$, compared to $0.37 \mathrm{mg} \mathrm{mm}^{-2}$ for the substrate. Conclusion: The results showed that clad steel gave better mechanical and oxidation properties compared to plain carbon steel substrate.
\end{abstract}

Key words: Clad layer, nitride, hardness, oxidation

\section{INTRODUCTION}

Surface treatments are critical to the engineering of modern machine components and tools, where the underlying material is chosen for its bulk properties (elastic modulus and hot hardness) while the surface is treated to provide the necessary surface properties (corrosion or wear resistance, for example) (Sproul and Legg, 1995). In order to enhance the surface properties, producers of components are turning to different surface treatments and in particular to hard protective coatings (Podgornik et al., 2001). Surface nitriding to form a hard protective layer is widely used to upgrade surface hardness, wear and corrosion resistance and fatigue strength of steels (Psyllaki et al., 2008). For a few decades, TiAlN coatings have been applied to tools, dies and many mechanical parts due to their excellent properties especially at high temperature, low density, high hardness, good electrical and thermal conductivity, high melting point and high corrosion resistance (Yoon et al., 2002; Munz, 1986; Zukerman et al., 2007).

A wide variety of methods are available to produce a hard coating layer including PVD, CVD, Laser surface cladding, Thermal spraying, Ion implantation (Psyllaki et al., 2008; Dutta Majumdar et al., 2008; Lopez et al., 2005). Surface melting treatments using high energy densities generate steep thermal gradients, which allow rapid solidification and at present, these have been achieved by electron beam processing or laser re-melting (Khan et al., 2000). All these processes have been successfully used to steels but they are expensive (Song and Shen, 1997; Koster and Schunemann, 1993).

The purpose of this study is to explore the possibility of producing hard cladding by $\mathrm{Ti}$ and $\mathrm{Al}$ powder replacement and TIG torch surface melting techniques. For surface melting, the heat energy is provided by the electric arc which is maintained between the tungsten electrode and the specimen. The effects of processing parameters on microstructure and properties have been studied.

\section{MATERIALS AND METHODS}

Plain carbon steel plate containing $0.2 \% \mathrm{C}$ was used as substrate with dimensions of $100 \times 45 \times 4 \mathrm{~mm}$. Before

Corresponding Author: S. Dyuti, Department of Manufacturing and Materials Engineering,

International Islamic University Malaysia, P.O. Box 10, 50728 Kuala Lumpur, Malaysia 
surface melting, the specimens were abraded with $\mathrm{SiC}$ paper and degreased using acetone. 1.3 and $1.8 \mathrm{mg} \mathrm{Ti}$ and $\mathrm{Al}$ powder mixtures per $\mathrm{mm}^{2}$ area of steel surfaces were used as the coating material. The powder mixture was made into a pasty mass mixing with PVA (polyvinyl acetate) binder and then placed on the substrate surfaces. The binder prevents the powder from blowing away during melting operation under the flow of shielding gas (Mridha et al., 2001). Binder is reported to be a source of pore formation in the resolidified zone, so the amount of PVA was restricted to $1 \mathrm{~mL}$ for $3 \mathrm{~g}$ of powder (Mridha and $\mathrm{Ng}, 1999$ ). The powder preplaced surface was then dried in an oven at $70^{\circ} \mathrm{C}$ for $1 \mathrm{~h}$ to remove moisture.

A Miller TIG torch heat source with a semiautomatic traversing arm was used for melting purpose. A $3.2 \mathrm{~mm}$ diameter non-consumable, thoriated tungsten electrode was used to strike an arc between the electrode and the work piece in nitrogen atmosphere under a flow rate of $40 \mathrm{~L} \mathrm{~min}^{-1}$. During melting operating currents were 80,90 and $100 \mathrm{~A}$ with $2 \mathrm{~mm} \mathrm{sec}^{-1}$ electrode traversing speed. The heat input of the TIG torch depends on the current used and it was calculated using the following formula (Easterling, 1992):

Heat input $=\frac{0.45 \times \text { current } \times \text { voltage }}{\text { Electrode traversing speed }}$

For metallographic examination, transverse sections of the tracks were polished and etched in nital. The clad layer was characterized by optical and scanning electron microscopy. A compositional analysis was carried out using energy dispersive spectroscopy and phase was identified by X-ray diffractometer. The Microhardness profiles as a function of melt depth was measured by a Vickers Microhardness tester using a $500 \mathrm{~g}$ applied load.

High temperature cyclic oxidation tests were carried out by heating the clad steel in a muffle furnace in air environment at $600^{\circ} \mathrm{C}$ for $72 \mathrm{~h}$. The test sample of $20 \times 10 \mathrm{~mm}$ rectangular plate was prepared by coating on both sides. After every $24 \mathrm{~h}$, the mass change of the specimens was measured using a METLER TOLEDO XS105 electronic balance with a weighing accuracy of $0.00001 \mathrm{~g}$. The oxide layer was characterized using SEM and EDX analyzer.

The formation of nitride clad layer by melting preplaced powder mixture of $50 \% \mathrm{Ti}$ and $50 \% \mathrm{Al}$ on steel surfaces under TIG torch in nitrogen environment has been presented and discussed.
Visual inspection of the melt track surface: All tracks processed with $\mathrm{Ti}$ and $\mathrm{Al}$ powder mixture of 1.3 and 1.8 $\mathrm{mg} \mathrm{mm}{ }^{-2}$ under energy inputs of 540-675 $\mathrm{J} \mathrm{mm}^{-1}$ were visually inspected and their surfaces were found fairly smooth and free from any obvious defects, (Fig. 1).

Melt pool size: The cross sections of the resolidified tracks processed under energy inputs of 540-675 $\mathrm{J} \mathrm{mm}^{-1}$ suggest completely melting of the powder layers along with a surface layer of the substrate material to form the clad layer. The width and depth of the clad layer produced under different energy inputs are listed in Table 1.

Results in Table 1 show that with $1.3 \mathrm{mg} \mathrm{mm}^{-2} \mathrm{Ti}$ and $\mathrm{Al}$ powder mixture, with increasing energy input, melting of the preplaced powder and larger amount of base metal created bigger melt pools. In all cases melt depths do not increase with the increase of energy input but together with pool width melt pool size is increased with energy input. At energy input of $608 \mathrm{~J} \mathrm{~mm}^{-1}$, melt pool size is smaller compared to that produced with $540 \mathrm{~J} \mathrm{~mm}^{-1}$ energy input. Maximum melt depth $3.07 \mathrm{~mm}$ is obtained when glazed with energy input of $540 \mathrm{~J} \mathrm{~mm}^{-1}$.

Melt configuration and microstructure: The microstructures of the clad layers produced with $1.3 \mathrm{mg} \mathrm{mm}^{-2}$ mixture of $50 \mathrm{wt} \% \mathrm{Ti}$ and $50 \mathrm{wt} \% \mathrm{Al}$ powder at different energy inputs are shown in Fig. 2 and 3.

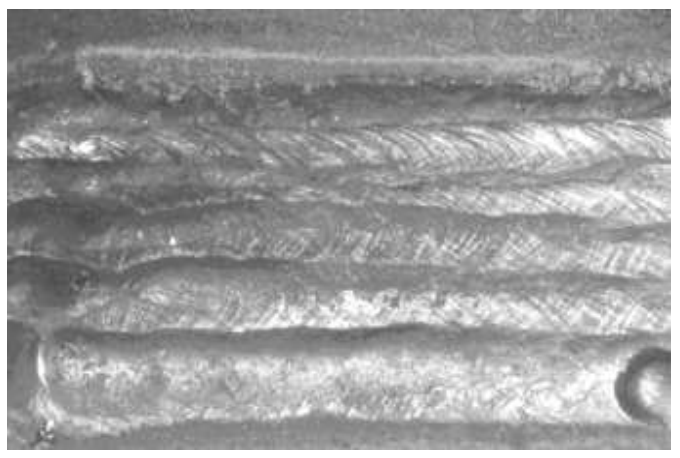

Fig. 1: Track produced with $1.3 \mathrm{mg} \mathrm{mm}^{-2}$ powder and glazed at $608 \mathrm{~J} \mathrm{~mm}^{-1}$ energy input

Table 1: Processing conditions and size of the melt pool

\begin{tabular}{lllll}
\hline $\begin{array}{l}\text { Energy } \\
\text { input } \\
\left(\mathrm{J} \mathrm{mm}^{-1}\right)\end{array}$ & $\begin{array}{l}1.3 \mathrm{mg} \mathrm{mm}^{-2} \mathrm{Ti}+\mathrm{Al} \\
\text { melted layer }(\mathrm{mm})\end{array}$ & $\begin{array}{l}1.8 \mathrm{mg} \mathrm{mm}^{-2} \mathrm{Ti}+\mathrm{Al} \\
\text { melted layer }(\mathrm{mm})\end{array}$ \\
\hline 540 & Depth & Width & Depth & Width \\
608 & 3.07 & 5.67 & 1.47 & 2.66 \\
675 & 1.67 & 4.89 & 2.31 & 5.77 \\
\hline
\end{tabular}




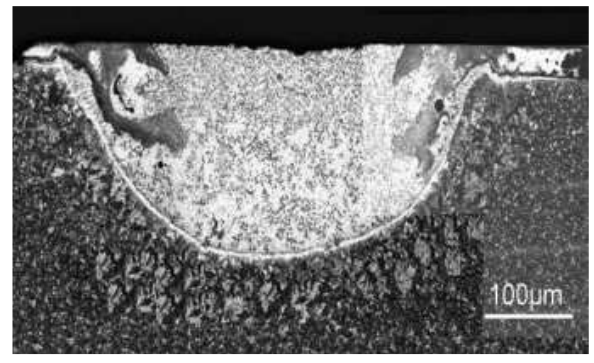

Fig. 2: Melt cross section of the mixture of $\mathrm{Ti}$ and $\mathrm{Al}$ powder melted clad $\left(1.3 \mathrm{mg} \mathrm{mm}^{-2} \mathrm{Ti}\right.$ and $\mathrm{Al}$, energy $540 \mathrm{~J} \mathrm{~mm}^{-1}$ )

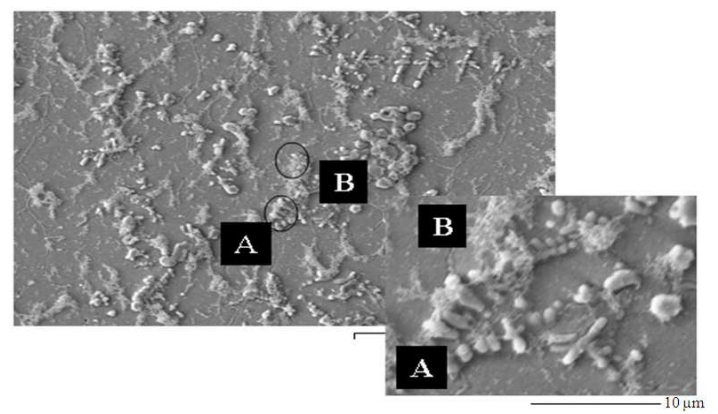

Fig. 3: Micrograph showing dendrite distribution in the clad layer processed with $\mathrm{Ti}$ and $\mathrm{Al}$ powder mixture of $1.3 \mathrm{mg} \mathrm{mm}^{-2}$ under energy input of $608 \mathrm{~J} \mathrm{~mm}^{-1}$

The melt cross sections gave a hemispherical shape with flow loop at the edge regions. Some pores were also observed at the edge regions (Fig. 2). The resolidified clad layer produced a dendrite microstructure and the features of dendrites are same in all tracks produced with different energy inputs, (Fig. 3). The dendrite concentration is high near the surface area compared to deeper melt depth, Fig. 2. The dendrites are very small in shape and distributed non-uniformly throughout the melt pool, as shown in Fig. 3.

The $1.8 \mathrm{mg} \mathrm{mm}^{-2}$ powder mixture tracks also gave hemispherical melt cross sections with porous edges, Fig. 4. The melt pool contains inhomogeneous dendrite distribution (Fig. 5). The concentration of dendrite population, in general, was higher near to the surface and it decreased with increasing the melt depth. Near the surface of the melt zone, the microstructure revealed fine dendrites (Fig. 5a) whereas at the bottom dendrites have coarser arms, as shown in Fig. 5 b.

XRD analysis: The XRD profiles of tracks processed with different amounts of $\mathrm{Ti}$ and $\mathrm{Al}$ powder mixtures are presented in Fig. 6 along with that of the substrate carbon steel. The $\mathrm{x}$-ray peaks from plain carbon steel shows the presence of $\alpha$-Fe phases only.

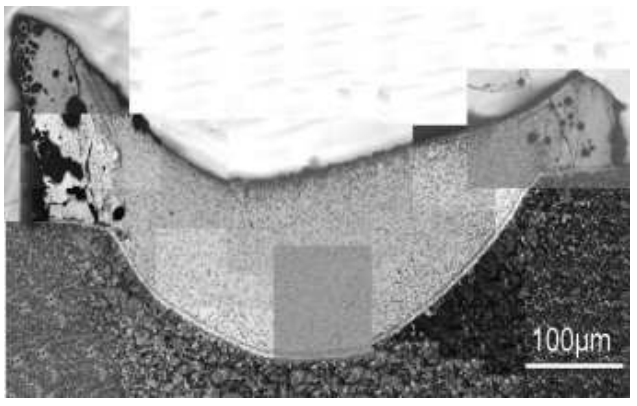

Fig. 4: Melt cross section of the mixture of $\mathrm{Ti}$ and $\mathrm{Al}$ powder melted clad $\left(1.8 \mathrm{mg} \mathrm{mm}^{-2} \mathrm{Ti}\right.$ and $\mathrm{Al}$, energy $675 \mathrm{~J} \mathrm{~mm}^{-1}$ )

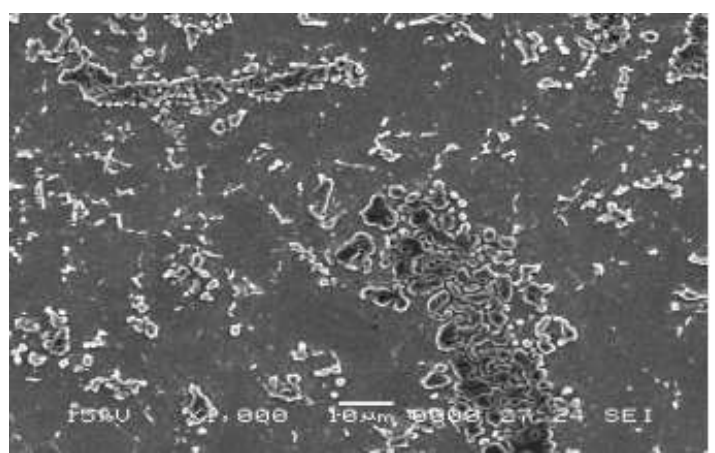

(a)

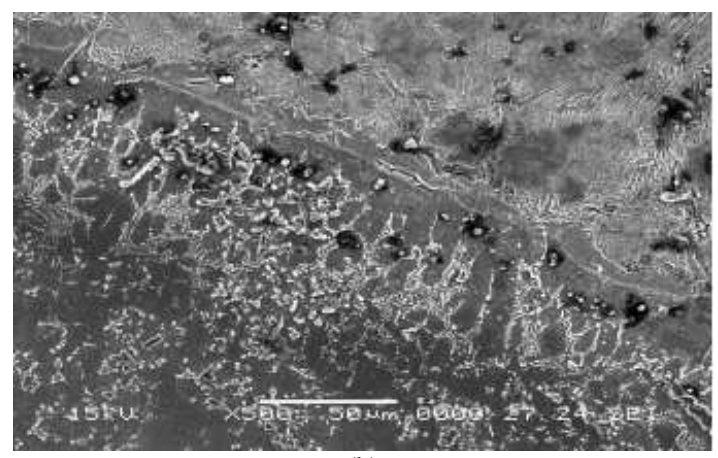

(b)

Fig. 5: Microstructure of the clad produced with $1.8 \mathrm{mg} \mathrm{mm}^{-2} \mathrm{Ti}$ and $\mathrm{Al}$ powder mixture under energy input of $675 \mathrm{~J} \mathrm{~mm}^{-1}$ (a) middle of the clad, (b) at the bottom of the clad.

The XRD peaks from the clad layers clearly show that all the tracks processed under different conditions formed nitride and intermetallic phases in the form of $\mathrm{Ti}_{3} \mathrm{Al}_{2} \mathrm{~N}_{2}$ and TiAl, $\mathrm{Al}_{3} \mathrm{Ti}, \mathrm{Ti}_{3} \mathrm{Al}$, Fig. $6 \mathrm{~b}$ and c.

EDS analysis: The EDS analysis of the mixture of $\mathrm{Ti}$ and Al clad surface is shown in Fig. 7 and 8 . 


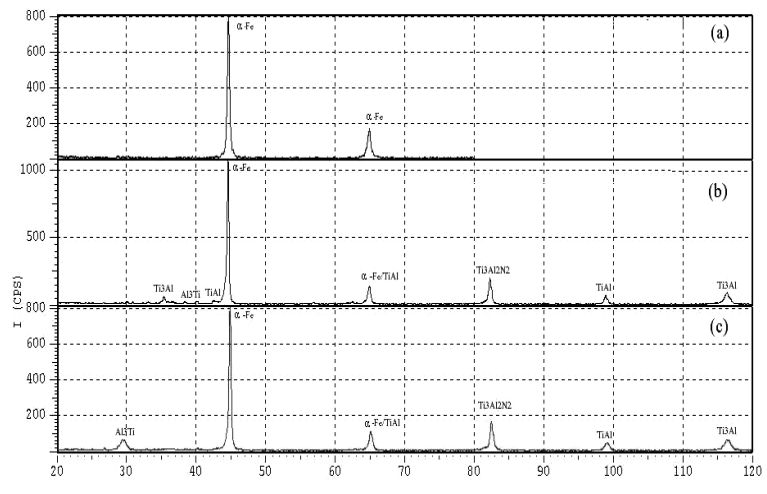

Fig. 6: XRD patterns of (a) plain carbon steel and tracks produced with $\mathrm{Ti}$ and $\mathrm{Al}$ powder mixture of (b) $1.3 \mathrm{mg} \mathrm{mm}^{-2}$ melted at $608 \mathrm{~J} \mathrm{~mm}^{-1}$ (c) $1.8 \mathrm{mg} \mathrm{mm}^{-2}$ melted at $675 \mathrm{~J} \mathrm{~mm}^{-1}$

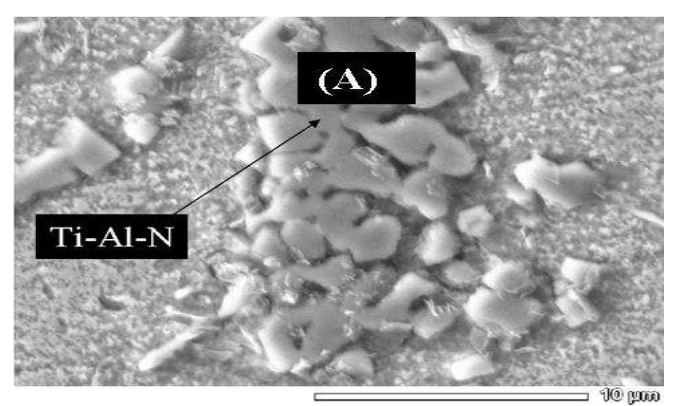

(a)

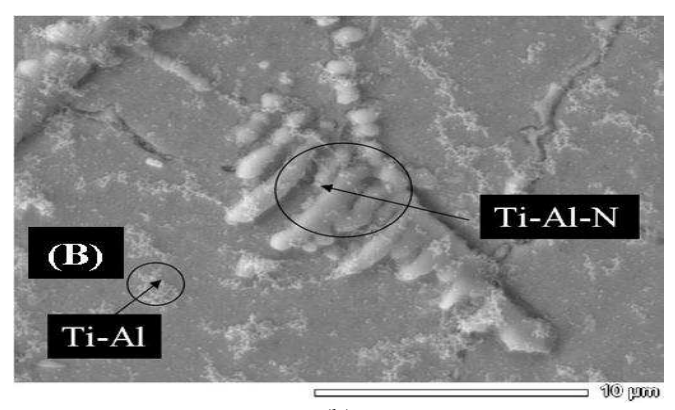

(b)

Fig. 7: EDS analysis within the clad processed with Ti and $\mathrm{Al}$ powder mixture of (a) $1.3 \mathrm{mg} \mathrm{mm}^{-2}$, melted at $608 \mathrm{~J} \mathrm{~mm}^{-1}$ (b) $1.8 \mathrm{mg} \mathrm{mm}^{-2}$, melted at $675 \mathrm{~J} \mathrm{~mm}^{-1}$

Elemental analysis within the indicated region in Fig. 7a shows large peaks (Fig. 8a) from titanium, aluminum and nitrogen and it is therefore considered to be a compound of Ti-Al-N. The region B in Fig. 7b shows two prominent peaks (Fig. 8b) from titanium and aluminum and there is no nitrogen.

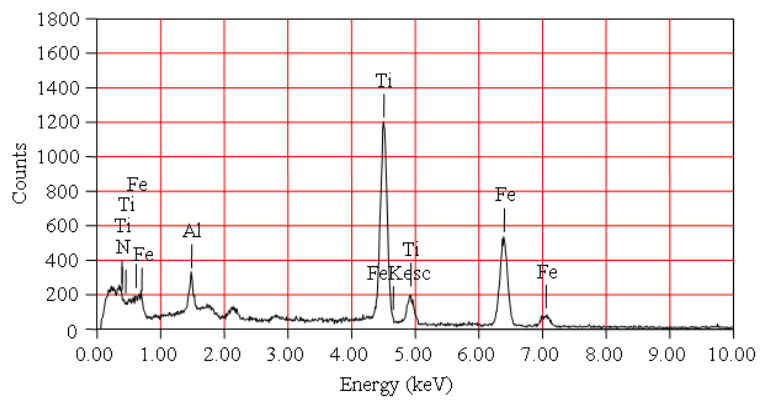

(a)

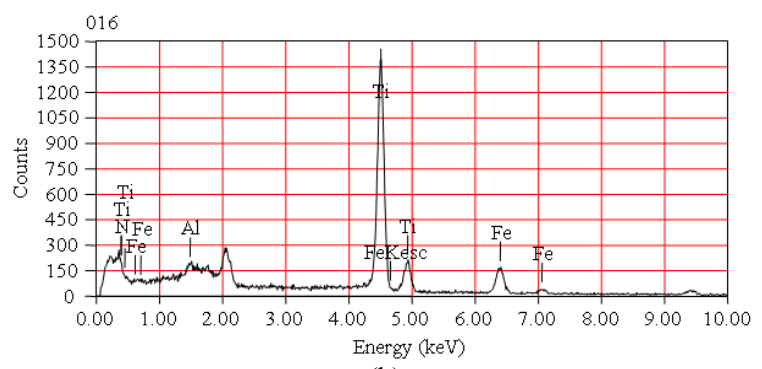

(b)

Fig. 8: Elemental distribution within the indicated zone as shown in (a) Fig. $7 \mathrm{a}$ and $\mathrm{b}$

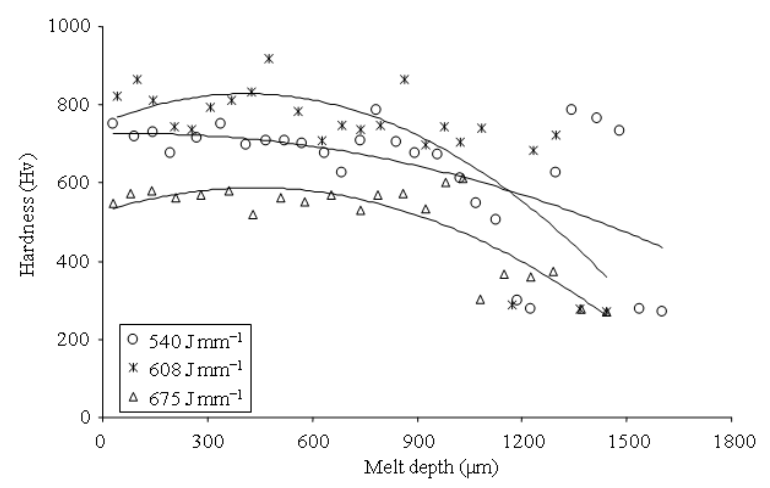

Fig. 9: Hardness of the clad steel produced with $1.3 \mathrm{mg} \mathrm{mm}^{-2}$ powder mixture

\section{Properties of the Ti-Al clad layers:}

Hardness: The Vickers hardness values of the various melt cross sections are measured from the surface towards the vertical melt depth. The hardness values plotted against the melt depth are shown in Fig. 9 and 10.

The cladding processed with $1.3 \mathrm{mg} \mathrm{mm} \mathrm{mm}^{-2}$ of $\mathrm{Ti}$ and $\mathrm{Al}$ powder mixture at $540,608 \mathrm{~J} \mathrm{~mm}^{-1}$ energy inputs showed maximum hardness of $788,918 \mathrm{Hv}$, respectively and these values are over 4.5 times the base hardness $(180 \mathrm{Hv})$, Fig. 9. Under these glazing conditions, the melt cross sections developed similar hardness profiles. The maximum hardness drops 
gradually toward the melt depth and finally drops below $300 \mathrm{Hv}$ at the fusion-matrix line at $1200 \mu \mathrm{m}$ melt depth. Tracks with energy input of $675 \mathrm{~J} \mathrm{~mm}^{-1}$ shows maximum hardness of $571 \mathrm{Hv}$ and slowly drops to $271 \mathrm{Hv}$ at $1441 \mu \mathrm{m}$ melt depth.

The hardness profiles of the track produced with $1.8 \mathrm{mg} \mathrm{mm}^{-2}$ of Ti and $\mathrm{Al}$ powder mixture with energy inputs of 540-675 $\mathrm{J} \mathrm{mm}^{-1}$ are given in Fig. 10. The tracks processed with energy inputs of 540, 608 and $675 \mathrm{~J} \mathrm{~mm}^{-1}$ produced similar hardness profiles with a maximum value around $600 \mathrm{Hv}$.

Oxidation properties: After oxidation at $600^{\circ} \mathrm{C}$ for $72 \mathrm{~h}$, the weight gains of the claddings, produced with 1.3 and $1.8 \mathrm{mg} \mathrm{mm}^{-2}$ of $\mathrm{Ti}$ and $\mathrm{Al}$ powder mixtures and glazed under different energy inputs of 608 and $675 \mathrm{~J} \mathrm{~mm}^{-1}$ respectively, are recorded and the oxidation kinetics of the claddings are presented in Fig. 11. The results in Fig. 11 give identical reaction kinetics at the initial stage of oxidation for the reference substrate material. It levels off after $24 \mathrm{~h}$ heating and again increases linearly. For the clad layers, it shows linear weight gain at the early stage and then slows down to parabolic growth. The weight gain of the reference material is 3 times to that of the clad layers and nearly linear with time indicating that the clad has very low oxidation compared to that of base metal.

Figure 12 shows a slight deviation in the linearity of the weight-gain squared against time curve for base metal. In comparison, this relationship for Ti-Al-N clad steel surface gives a perfect linear fitting, indicating a true parabolic oxidation behavior. This behavior suggests a diffusion-controlled growth of the oxide layer on the clad surface (Mridha, 2004; Feng et al., 2006). The oxide growth rates on reference sample and Ti-Al-N clad steel surface have been determined from Fig. 12 and they are found to be $19.4 \times 10^{-4}, 2.9 \times 10^{-4}$ and $2.3 \times 10^{-4} \mathrm{mg}^{2} \mathrm{~mm}^{-4} \mathrm{~h}^{-1}$ for substrate and with the $1.3,1.8 \mathrm{mg} \mathrm{mm}^{-2}$ of $\mathrm{Ti}$ and $\mathrm{Al}$ powder tracks processed at 608 and $675 \mathrm{~J} \mathrm{~mm}^{-1}$ respectively. These findings suggest that $1.3 \mathrm{mg} \mathrm{mm}^{-2} \mathrm{Ti}$ and $\mathrm{Al}$ powder track processed at $608 \mathrm{~J} \mathrm{~mm}^{-1}$ has the highest (6 times) oxidation resistance than the substrate sample.

The cross sections of the oxidized uncoated and mixture of $1.3 \mathrm{mg} \mathrm{Ti}$ and $\mathrm{Al}$ coated steel surfaces are presented in Fig. 13, which show a thick oxide layer on the uncoated substrate surface while a thin and adherent oxide layer on the clad surface.

EDX analysis within the oxide zone of the Ti-Al clad layer gives peaks from $\mathrm{Fe}, \mathrm{Ti}, \mathrm{Al}$ and $\mathrm{O}$, Fig. 14. This indicates that the clad layer is a mixture of $\mathrm{Fe}_{2} \mathrm{O}_{3}$, $\mathrm{Al}_{2} \mathrm{O}_{3}$ and $\mathrm{TiO}_{2}$. It is to be noted that $\mathrm{TiO}_{2}$ and $\mathrm{Al}_{2} \mathrm{O}_{3}$ are always very adherent to the substrate surface while iron oxide spalls from the surface.

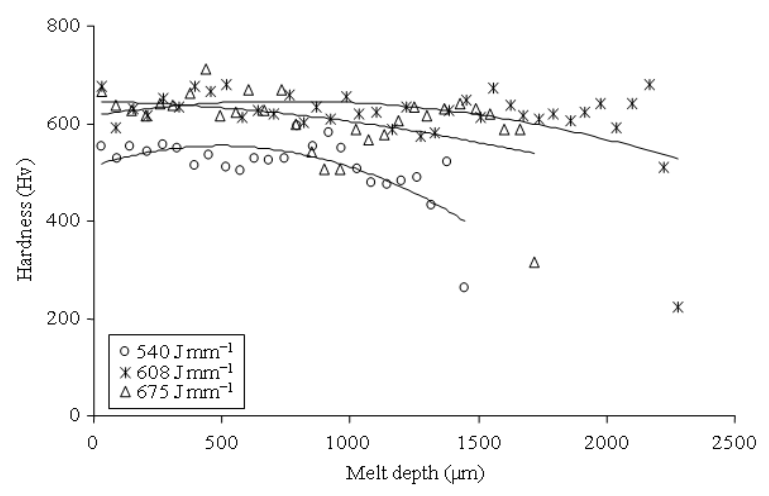

Fig. 10: Hardness of the clad steel produced with $1.8 \mathrm{mg} \mathrm{mm}^{-2}$ powder mixture

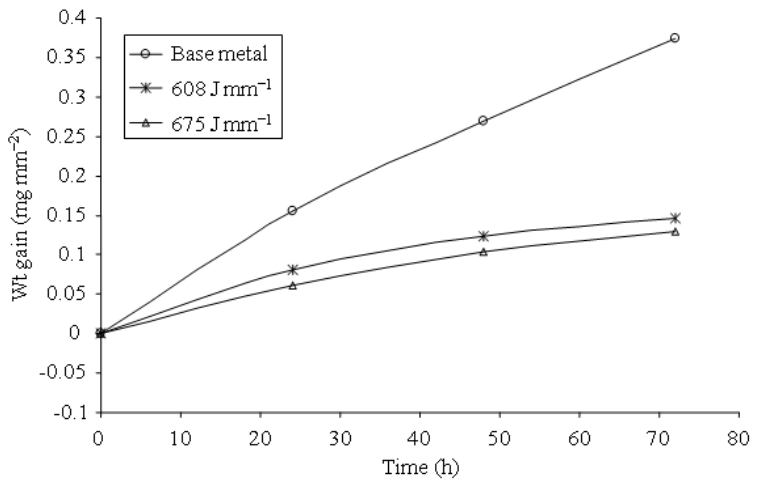

Fig. 11: Oxidation kinetics of the $\mathrm{Ti}$ and $\mathrm{Al}$ clad layer and base metal

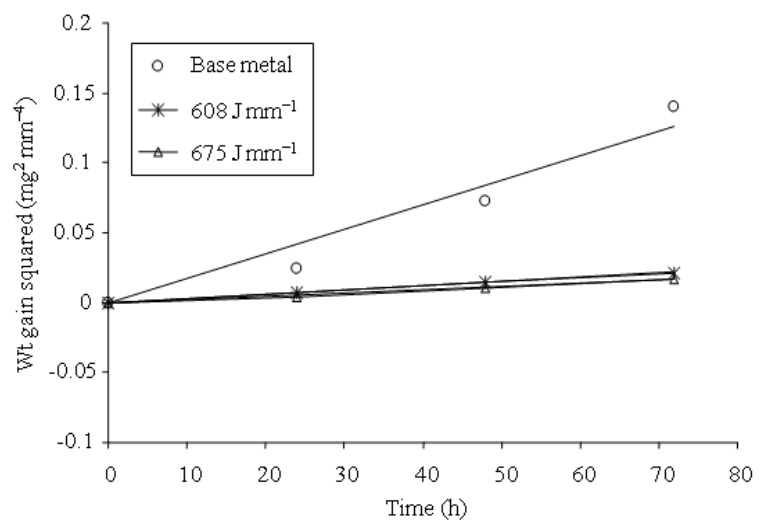

Fig. 12: Plot of weight-gain squared against time for reference sample and Ti-Al-N clad steel 


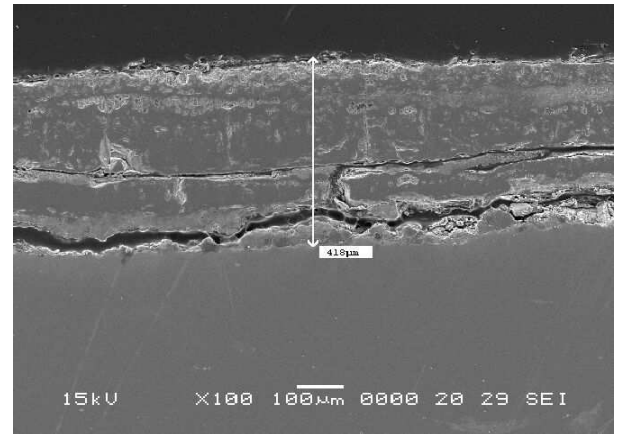

(a)

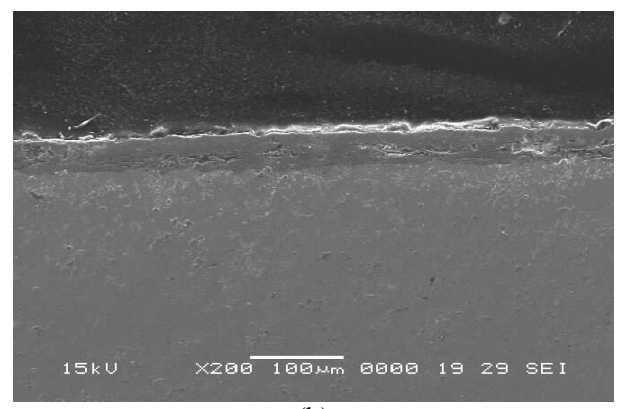

(b)

Fig. 13: SEM micrograph of the oxide layer after cyclic oxidation for $72 \mathrm{~h}$ at $600^{\circ} \mathrm{C}$, (a) base metal (b) Ti-Al clad layer

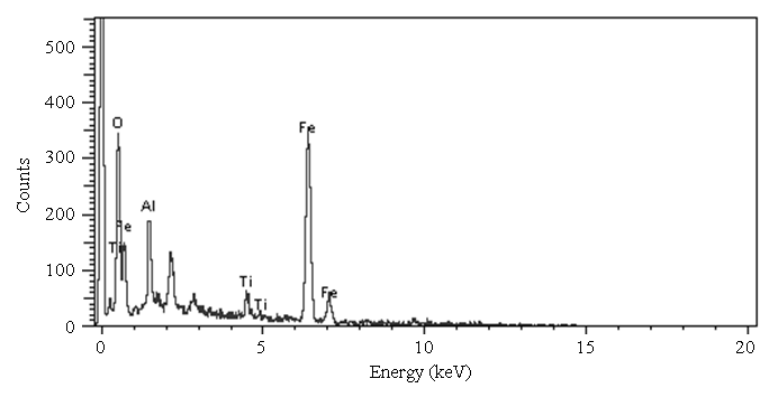

Fig. 14: EDX analysis of the Ti-Al-N clad layer

\section{RESULTS AND DISCUSSION}

Ripple marks were observed on the resolidified track surfaces which are suggested to have formed due to rapid solidification of the melt (Mridha, 2005). Results in Table 1 show that glazing of aluminum and titanium powder mixture needs high energy input because of high thermal conductivity of aluminum (Kou, 2003). Also the melt size depends on energy input. During glazing the energy input is influenced by the operating current, electrode traversing speed and arc length of the electrode. Glazing with high electrode speed produces low energy input and causes small melt depth (Kou, 2003). In this experiment arc length was maintained between 1-2 $\mathrm{mm}$. Due to the variation of the arc length, arc voltage varies and affects the melt pool width (Cary, 1995). The shape of the electrode tip also affects the shape and power density distribution of the arc (Kou, 2003). Cary (1995) cited that, under the same operating current, voltage and the arc gap, the melt depth-width ratio increases with increasing vertex angle of the conical tip of the tungsten electrode. The formation of flow loops in the melt cross section with high concentration of dendrite is due to the Maragoni convectional fluid flow (Kou, 2003; Lancaster, 1993). This type of flow loops are also observed in other work of laser nitriding (Mridha and Baker, 1998). The preplaced powder flowed along the loop in the melt and that caused high concentration of added metal in the melt and this precipitated more dendrites along the high concentration loop lines. The presence of porous edges has been attributed to the evolution of excess nitrogen gas from the solidifying melt pool.

During surface melting in nitrogen environment, a large quantity of nitrogen gas entered into the melt pool (Mridha, 2005). On solidification, the excess nitrogen in the liquid, which did not react with the melt, escaped via the surface of the melt pool. Because of the Gaussian energy distribution of the torch the centre region of the melt track attained higher temperature than to the edges. As such the melt temperature at the edges was lower and on subsequent solidification the escaping gas left pores at these regions; the viscous melt was unable to fill up the pores and thus produced porous regions.

The formation of finer dendrites near the surface with random orientations is believed to be due to the quick solidification of the melt at the surface. Nearer the surface of the melted zone, the dissolved nitrogen is expected to be the highest and the cooling rate is the fastest compared to the bottom of the melt which causes variation in dendrite distribution (Mridha, 2005).

During melting of the preplaced $\mathrm{Ti}$ and $\mathrm{Al}$ powder in nitrogen environment, nitrogen dissolved in the liquid melt and this nitrogen reacted with $\mathrm{Ti}$ and $\mathrm{Al}$ to form nitrides; both of them are nitride forming elements (Lancaster, 1993). Also intermetallic of $\mathrm{Ti}$ and $\mathrm{Al}$ formed in the melt. The thickness of the preplaced powder mixture, energy density of the glazing torch along with nitrogen dissolution in the melt is believed to be responsible to control the formation of different phases in the alloyed layers. As steel is the base metal, a large peak come from iron. Therefore phases in region $\mathrm{B}$ is thought to be Ti-Al intermetallic. XRD analysis also suggests the existence of these phases.

Glazing at higher energy input caused melting of larger amount of base metal and that diluted the melt 
pool which created lesser titanium and aluminum nitride particles. This is one of the reasons why hardness is lower when glazed at higher energy densities. The hardness developed by the formation of nitrides (from the reaction between $\mathrm{Ti}, \mathrm{Al}$ and the dissolved nitrogen) upon solidification. During melting of $\mathrm{Ti}$ and $\mathrm{Al}$ powder mixture preplaced surface in nitrogen atmosphere, nitrogen is dissolved in the melt. As $\mathrm{Ti}$ and $\mathrm{Al}$ are nitride forming elements, during solidification they react with nitrogen and form titanium-aluminum-nitride in the form of dendrites. These dendrites in the melt give relatively high hardness. During solidification some reactions between titanium and aluminum also occur to form $\mathrm{Ti}-\mathrm{Al}$ intermetallic. The uniform distribution of this intermetallic (Fig. 2) shows stable hardness profiles throughout the melt cross section. The hardness development throughout the melt cross section was in the range of 600-800 Hv. Similar hardness development was observed in other works of Ti-Al intermetallic coating formation (Mridha et al., 2001). Near the fusion zone, the cooling was low enough for some dendrite growth and the increase in dendrite size (Fig. 3b) further reduced the hardness.

The presence of titanium oxide and aluminium oxide at the surface make the matrix more protected from further oxidation. In other words, diffusion of oxygen through these titanium and aluminium oxides becomes very slow and hence the clad layer offers higher oxidation resistance.

\section{CONCLUSION}

A composite layer of around $1 \mathrm{~mm}$ thick can be produced by melting $1.3,1.8 \mathrm{mg} \mathrm{mm}^{-2}$ preplaced Ti and Al powder mixtures in nitrogen environment under a TIG torch with energy inputs between 540-675 $\mathrm{J} \mathrm{mm}^{-1}$ with a TIG torch. The clad layer has dendritic microstructures and the dendrites are mainly $\mathrm{Ti}-\mathrm{Al}$ nitrides and $\mathrm{Ti}-\mathrm{Al}$ intermetallic which were distributed in-homogeneously throughout the melt pool. The hardness of the track is found to depend on dendrite population and maximum hardness varied between 900-233 Hv over a melt depth of $2000 \mu \mathrm{m}$. Cyclic oxidation test on the clad layer gave a weight gain of $0.13 \mathrm{mg} \mathrm{mm}$ after heating at $600^{\circ} \mathrm{C}$ for $72 \mathrm{~h}$ in air environment compared to $0.37 \mathrm{mg} \mathrm{mm}^{-2}$ for the plain carbon steel.

\section{ACKNOWLEDGMENT}

Researchers are thankful to the Faculty of Engineering and Research Management Center of IIUM for financial support to conduct this study.

\section{REFERENCES}

Cary, H.B., 1995. Arc Welding Automation. 1st Edn., CRC Press, New York., ISBN: 10: 0824796454, pp: 325.

Dutta Majumdar, J., B. Ramesh Chandra, A.K. Nath and I. Manna, 2008. Studies on compositionally graded silicon carbide dispersed composite surface on mild steel developed by laser surface cladding. J. Mater. Process. Technol., 203: 505-512. DOI: 10.1016/j.jmatprotec.2007.10.056

Easterling, K.E., 1992. Introduction to Physical Metallurgy of Welding. Butterworth-Heinemann, London, ISBN: 13: 978-0750603942, pp: 25-40.

Feng, C., M. Li, L. Xin and S. Zhu, 2006. Mechanical properties and oxidation behavior of a graded (Ti,Al)N coating deposited by Arc-Ion-Plating. Oxidat. Metals, 65: 307-327. DOI: 10.1007/s11085-006-9015-0

Khan, T.I., S.A. Rizvi and K. Matsuura, 2000. The effect of wear behavior of H13 tool surfaces modified using a tungsten arc heat source. Wear, 244: 154-164. DOI: $10.1016 / S 0043-$ 1648(00)00453-1

Koster, U. and U. Schunemann, 1993. Rapidly Solidified Surface Layers by Laser Melting. In: Rapidly Solidified Alloys, Liebermann, H.H. (Ed.). Marcel Dekker, New York, ISBN: 10: 0824789512, pp: 95.

Kou, S., 2003. Welding Metallurgy. 2nd Edn., WileyInter-Science Publication, USA., ISBN: 9780471434917, pp: 37-59.

Lancaster, J.F., 1993. Metallurgy of Welding. 5th Edn., Chapman and Hall, London, ISBN: 10: 0412478102, pp: 256.

Lopez, D., C. Sanchez and A. Toro, 2005. Corrosionerosion behavior of TiN-coated stainless steels in aqueous slurries. Wear, 258: 684-692. DOI: 10.1016/j.wear.2004.09.015

Mridha, S. and B.S. Ng, 1999. Additions of ceramic particles to TIG melted titanium surfaces. Surf. Eng., 15 : 210-215. DOI: $10.1179 / 026708499101516533$

Mridha, S. and T.N. Baker, 1998. Effects of nitrogen gas flow rates on the microstructure and properties of laser-nitrided IMI318 titanium alloy (Ti-4V6Al). J. Mater. Process. Technol., 77: 115-121.

Mridha, S., 2004. High temperature oxidation resistance of TIG melted titanium aluminide coatings. Proceeding of the 2nd International Industrial Engineering Conference, Dec. 19-24, World Scientific Publisher, Riyadh, Saudi Arabia. 
Mridha, S., 2005. Titanium nitride layer formation by TIG surface melting in a reactive environment. J. Mater. Process. Technol., 168: 471-477. DOI: 10.1016/j.jmatprotec.2005.02.247

Mridha, S., H.S. Ong, L.S. Poh and P. Cheang, 2001. Intermetallic coatings produced by TIG surface melting. J. Matter. Process. Technol., 113: 516-520.

Munz, W.D., 1986. Titanium aluminum nitride films: A new alternative to TiN coatings. J. Vac. Sci. Technol. A, 4: 2717-2725. DOI: 10.1116/1.573713

Podgornik, B., J. Vizintin, O. Wanstrand, M. Larsson and S. Hogmark et al., 2001. Tribological properties of plasma nitrided and hard coated AISI 4140 steel. Wear, 249: 254-259. DOI: 10.1016/S0043-1648(01)00564-6

Psyllaki, P.P., A. Griniari and D.I. Pantelis, 2008. Parametric study on laser nitriding of 1.5919 steel. J. Mater. Process. Technol., 195: 299-304. DOI: 10.1016/j.jmatprotec.2007.05.023
Song, Q. and L. Shen, 1997. Microstructural feature of laser surface melting $1 \mathrm{Cr} 17 \mathrm{Ni} 2$ stainless steel. Scripta Mater., 36: 531-534. DOI: 10.1016/S13596462(96)00417-4

Sproul, W.D. and K.O. Legg, 1995. Advanced Surface Engineering. Technomic Publishing Co., USA., ISBN: 0791842029, pp: 181.

Yoon, S.Y., K.O. Lee, S.S. Kang and K.H. Kim, 2002. Comparison for mechanical properties between TiN and TiAlN coating layers by AIP technique. J. Mater. Process. Technol., 130-131: 260-265. DOI: 10.1016/S0924-0136(02)00746-X

Zukerman, I., A. Raveh, H. Kalman, J.E. KlembergSapieha and L. Martinu, 2007. Thermal stability and wear resistance of hard TiN/TiCN coatings on plasma nitride PH15-5 steel. Wear, 263: 1249-1252. DOI: $10.1016 /$ j.wear.2006.11.049 